\title{
Artificial barriers prevent genetic recovery of small isolated populations of a low-mobility freshwater fish
}

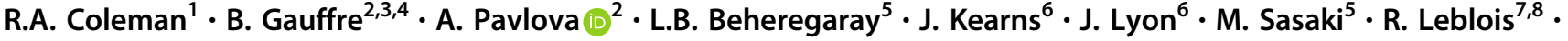 \\ C. Sgro ${ }^{2} \cdot$ P. Sunnucks $\mathbb{1}^{2}$
}

Received: 27 July 2017 / Revised: 5 September 2017 / Accepted: 8 September 2017 / Published online: 12 January 2018

(c) The Author(s) 2018. This article is published with open access

\begin{abstract}
Habitat loss and fragmentation often result in small, isolated populations vulnerable to environmental disturbance and loss of genetic diversity. Low genetic diversity can increase extinction risk of small populations by elevating inbreeding and inbreeding depression, and reducing adaptive potential. Due to their linear nature and extensive use by humans, freshwater ecosystems are especially vulnerable to habitat loss and fragmentation. Although the effects of fragmentation on genetic structure have been extensively studied in migratory fishes, they are less understood in low-mobility species. We estimated impacts of instream barriers on genetic structure and diversity of the low-mobility river blackfish (Gadopsis marmoratus) within five streams separated by weirs or dams constructed 45-120 years ago. We found evidence of small-scale $(<13 \mathrm{~km})$ genetic structure within reaches unimpeded by barriers, as expected for a fish with low mobility. Genetic diversity was lower above barriers in small streams only, regardless of barrier age. In particular, one isolated population showed evidence of a recent bottleneck and inbreeding. Differentiation above and below the barrier $\left(F_{\mathrm{ST}}=0.13\right)$ was greatest in this stream, but in other streams did not differ from background levels. Spatially explicit simulations suggest that short-term barrier effects would not be detected with our data set unless effective population sizes were very small $(<100)$. Our study highlights that, in structured populations, the ability to detect short-term genetic effects from barriers is reduced and requires more genetic markers compared to panmictic populations. We also demonstrate the importance of accounting for natural population genetic structure in fragmentation studies.
\end{abstract}

\section{Introduction}

Widespread loss of habitat and associated fragmentation of wildlife populations is a major threat to global biodiversity (Sala et al., 2000; Foley et al., 2005; Fischer and Lindenmayer, 2007). Fragmentation often results in small, isolated

Electronic supplementary material The online version of this article (https://doi.org/10.1038/s41437-017-0008-3) contains supplementary material, which is available to authorized users.

R. A. Coleman

rhys.coleman@melbournewater.com.au

1 Applied Research, Melbourne Water Corporation, Docklands, VIC 3008, Australia

2 School of Biological Sciences, Monash University, Clayton, VIC 3800, Australia

3 Centre d'Etudes Biologiques de Chizé, UMR 7372, CNRS and Université de La Rochelle, F-79360 Beauvoir sur Niort, France

4 INRA, USC 1339 CEBC, F-79360 Villiers en Bois, France populations that are more vulnerable to stochastic events. For example, fluctuations in climate such as drought, natural catastrophes such as wildfires and demographic variation such as annual breeding success. As a consequence small, isolated populations are vulnerable to loss of genetic diversity through genetic drift (Fischer and Lindenmayer, 2007). Loss of genetic diversity contributes to increased extinction risk for small populations, because it reduces the potential of populations to adapt to future environmental changes such as disease, pollutants, and climate change, and

5 Molecular Ecology Lab, Flinders University, Adelaide, SA 5001, Australia

6 Arthur Rylah Institute for Environmental Research, Department of Environment, Land, Water and Planning, Heidelberg, VIC 3084, Australia

7 CBGP, INRA, CIRAD, IRD, Montpellier SupAgro, University of Montpellier, Montpellier, France

8 Institut de Biologie Computationnelle, University of Montpellier, Montpelier, France 
can result in loss of fitness through inbreeding and fixation of deleterious alleles (Frankham, 2005; Willi et al., 2006). Loss of genetic diversity in small, isolated populations has been observed across a broad range of taxonomic groups including mammals, birds, reptiles, and fishes (Frankham, 1996; Taylor et al., 2003; Whiteley et al., 2013; RiveraOrtíz et al., 2014). Where population isolation and loss of genetic diversity through drift threatens the viability of small populations, the managed movement of individuals into these populations from a suitable source population (assisted gene flow) can rapidly increase genetic diversity and improve population fitness (Frankham, 2015; Whiteley et al., 2015). Thus, assessing levels of genetic diversity and the strength of genetic drift after population isolation can assist in developing effective conservation strategies.

Freshwater ecosystems are especially vulnerable to habitat loss and fragmentation, given the linear nature of rivers and streams and the need for many aquatic organisms to undertake longitudinal (upstream and downstream) and lateral (notably onto adjacent floodplains during high flows) movements as a part of their life history. Along with other threats, such as overexploitation, water pollution, flow modification, and invasion by exotic species, these aspects of freshwater ecosystems have contributed to a proportionally higher number of threatened freshwater species per area compared to terrestrial and marine ecosystems (Dudgeon et al., 2006; Strayer and Dudgeon, 2010). Artificial barriers to the movement of freshwater organisms include dams, pipes, culverts, weirs, levees, altered flow regimes, and aquatic pollution, with many freshwater systems affected worldwide (Jackson et al., 2001; Nilsson et al., 2005). Here we use the term "barrier" to mean any restriction to the movement of individuals and their genes. The negative impacts of barriers on fish distribution and abundance have been well documented, and with $>60 \%$ of the world's 227 largest rivers classified as highly fragmented, barriers are recognised as a major threat to freshwater fishes (Lucas et al., 2001; Reid et al., 2013; Hansen et al., 2014). In some cases, fragmentation due to dams has led to extirpation of populations, while in others it has exerted negative genetic effects by restricting gene flow and causing population declines (Angermeier, 1995; Faulks et al., 2011; Hansen et al., 2014).

To understand the threats associated with barriers to freshwater fish communities and find appropriate management solutions, it is important to evaluate the genetic consequences of barriers for species with a range of mobility. While several studies have assessed the impact of natural or artificial barriers on genetic structure and diversity of freshwater fish species that have the potential to move substantial distances throughout their life, especially salmonid species (for example, Morita and Yamamoto, 2002; Costello et al., 2003; Taylor et al., 2003; Wofford et al., 2005; Beneteau et al., 2009; Whiteley et al., 2013; Gouskov et al., 2016), studies of non-salmonid and lowmobility species are comparatively rare in the fragmentation literature (Dehais et al., 2010; Roberts et al., 2013; Lean et al., 2017). Assessing the impact of recent barriers on genetic structure is challenging for species with low mobility: when mating occurs preferentially within areas that are small relative to the global population range, genetic differentiation can increase across the landscape with distance (isolation-by-distance (IBD), Wright, 1943). In such structured populations, the rate of loss of genetic variability globally is reduced compared to a panmictic population of the same size (Leblois et al., 2006), and so it takes more generations for the genetic signature of a barrier effect to develop (Landguth et al., 2010). To avoid erroneously attributing pre-existing genetic structure to barrier effects, background levels of spatial genetic structure must be considered.

In this study, we focus on the impacts of artificial barriers on the genetic structure and diversity of a non-migratory freshwater fish species, the southern river blackfish, Gadopsis marmoratus. As well as having low mobility, this highly territorial species has low fecundity, making its small populations highly vulnerable to environmental stochasticity (Jackson et al. 1996; Huey et al., 2017). Over much of its range, the distribution of $G$. marmoratus is contracting and population sizes are declining (Morris et al., 2001; Lintermans, 2007; Hammer et al., 2009; Huey et al., 2017; Unmack et al., 2017). Recent genetic studies of G. marmoratus across the Murray-Darling Basin (Lean et al., 2017) and in northern south-eastern Australia (Huey et al., 2017) showed low local genetic diversity, suggestive of limited capacity of small populations to adapt to future environmental changes. In addition, strong genetic structure was found at both large and small spatial scales, suggestive of low gene flow across sites and strong effects of genetic drift. While no IBD was detected in both studies, it was suggested that patterns of IBD could be detected over the spatial scale of a stream or catchment unimpeded by barriers. It remains unclear whether the observed genetic structure in G. marmoratus is a natural outcome of low dispersal or a result of the combined effect of low dispersal and habitat fragmentation. Here we test for an effect of artificial barriers on genetic structure in G. marmoratus in south-eastern Australia at a small spatial scale (from 1.5 to $15 \mathrm{~km}$ within individual streams) after accounting for natural genetic structure. The upper Yarra River system near Melbourne, Victoria, Australia presents an excellent opportunity to design an assessment of the impacts of barriers of known age on the genetic structure of a lowmobility freshwater fish. In response to Melbourne's human population growth, a network of stream flow diversion weirs of known age has progressively increased in extent in 
the upper Yarra River system, with staged installation of water supply weirs and dams since 1893 .

We aimed to test the hypothesis that isolation of a lowmobility freshwater fish by artificial barriers increases genetic drift upstream, resulting in (1) stronger differentiation between populations above and below barriers than would be expected under natural processes, and (2) reduced genetic diversity and inbreeding within populations above barriers compared to populations below barriers. More specifically, we predicted that loss of genetic diversity in populations above each barrier and genetic differentiation across the barrier would depend on (1) the age of the barrier, (2) the size of the above-barrier population (based on catchment area) and (3) the disturbance history (for example, wildfire and severe drought) that could lead to bottlenecks compounding genetic drift due to fragmentation. To achieve our aims, we analysed microsatellite DNA marker data for populations above and below water supply barriers in five streams, where barrier ages were 45-120 years old ( 9-24 G. marmoratus generations) and catchment sizes were $14-337 \mathrm{~km}^{2}$. To assess our ability to distinguish barrier effects from background genetic structure, we first estimated the background levels of differentiation across sample sites within connected parts of the catchment. We then simulated the effects of genetic drift on genetic diversity and differentiation $\left(F_{\mathrm{ST}}\right)$ across a barrier for different densities of populations with background genetic structure similar to those estimated in our observed data set. We also used simulations to investigate whether barrier effects on genetic differentiation were masked by unidirectional downstream gene flow (Dehais et al., 2010; Roberts et al., 2013).

\section{Materials and methods}

\section{Study area}

The Yarra River catchment, Victoria, Australia, covers a total area of over $4000 \mathrm{~km}^{2}$, with our study area comprising two distinct sub-catchments: the Watts River sub-catchment (including Donnellys Creek) and the upper Yarra River subcatchment (including Armstrong and McMahons creeks) (Fig. 1). Land use in the Watts River sub-catchment is $81.0 \%$ forested, $15.1 \%$ rural and $3.9 \%$ urban, and in the upper Yarra River sub-catchment is $99.3 \%$ forested and $0.7 \%$ rural. There are also two distinct stream types: rivers with large catchments and reservoirs (upper Yarra River $337 \mathrm{~km}^{2}$, Upper Yarra Reservoir-capacity 200,579 megalitres (ML) and surface area 777 ha; Watts River $165 \mathrm{~km}^{2}$, Maroondah Reservoir-22,179 ML, 199 ha) and creeks with small catchment areas and diversion weirs (Donnellys Creek-14 km², McMahons Creek-44 km² and Armstrong
Creek-55 $\mathrm{km}^{2}$ ) (Table 1). At the time of this study, the ages of water supply structures in the upper Yarra River system were 45-120 years, with Donnellys Creek weir being the oldest, constructed in 1893. Maroondah Reservoir in the Watts River was constructed in 1927, Upper Yarra Reservoir in the Yarra River in 1959, and Armstrong Creek and McMahons Creek weirs in 1968. The heights of these structures range from $\sim 1.5 \mathrm{~m}$ (Donnellys Creek weir) to 91 m (Upper Yarra dam), with heights for Maroondah dam on the Watts River, Armstrong weir, and McMahons weir being $\sim 41 \mathrm{~m}, 4.5 \mathrm{~m}$ and $2.7 \mathrm{~m}$, respectively. Although occasional downstream migrations may occur over the smaller barriers (namely, Donnellys, McMahons, and Armstrong creeks), all barriers were expected to permanently restrict upstream movement for the study species. The main disturbance events that occurred since installation of the water supply barriers were droughts and wildfires. Significant droughts that affected the entire study area were during 1967-1968, 1982-1983, and late 1996-mid 2010. Wildfires in 1983 affected the entire McMahons Creek system, and small areas and Armstrong and Upper Yarra below the barriers (Woodgate, 1984), and wildfires in 2009 resulted in severe burning of substantial areas of the Armstrong Creek catchment above the barrier, and low-severity burning within the Donnellys Creek and Watts River catchments (Feikema et al., 2013).

\section{Southern river blackfish (Gadopsis marmoratus)}

Gadopsis marmoratus sensu lato has a range across southeastern Australia, being widespread in Victoria and present in parts of south east Queensland, eastern New South Wales and south east South Australia (Allen et al., 2002). Differences in morphological features and multiple genetic studies indicate that G. marmoratus represents a species complexmost notably between "northern" and "southern" geographic regions (Sanger, 1986; Ovenden et al., 1988; Miller et al., 2004; Ryan et al., 2004; Hammer et al., 2014). The candidate species in this study, the southern-basin lineage ("SBA"), includes Victorian and Tasmanian systems draining to Bass Strait (Hammer et al., 2014; Unmack et al., 2017).

Based on 757 G. marmoratus individuals from our study area, Sanger (1986) measured a mean total length of 157 $\mathrm{mm}$ (range $27-420 \mathrm{~mm}$ ) and growth rates of $\sim 40 \mathrm{~mm} /$ year for the first 6 years of life. Their lifespan is at least 8 years (Sanger, 1986; Koehn et al., 1994), with sexual maturity of females from 2 years old (Sanger, 1986). On the basis of these sexual maturity and lifespan estimates, we assume a generation time of 5 years for G. marmoratus, which corresponds to between 9 and 24 generations of isolation due to the construction of water supply barriers in this study. Annual fecundity is low (usually $<500$ eggs), increasing 
a)

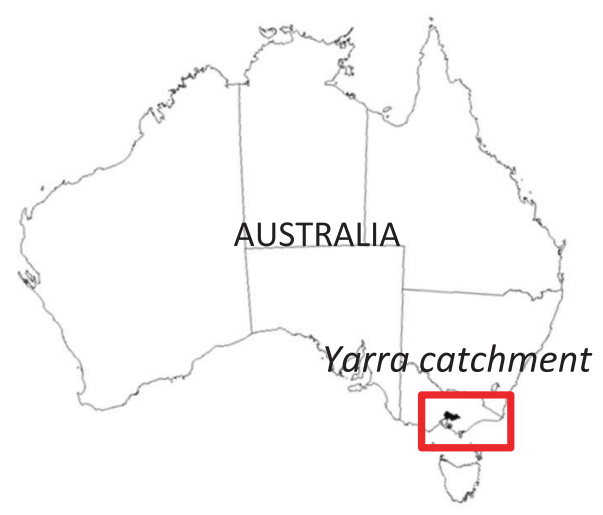

c)
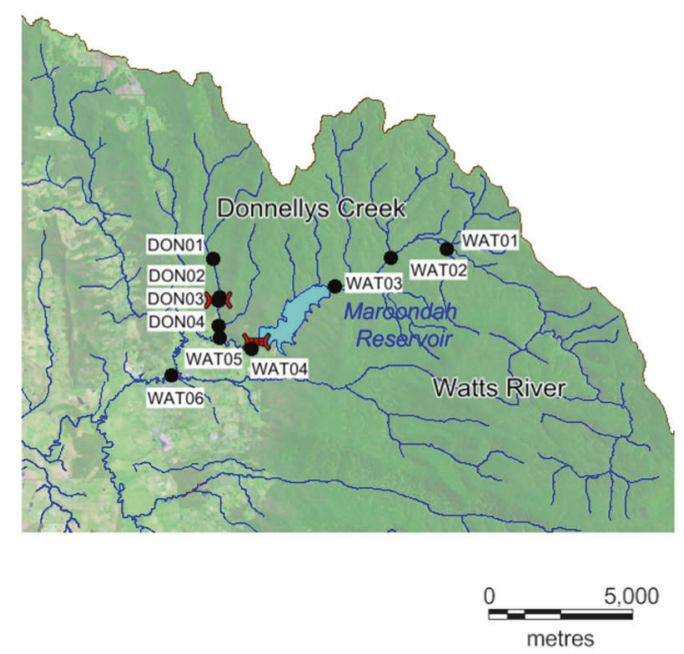

Scale: $1: 179,300$ b)

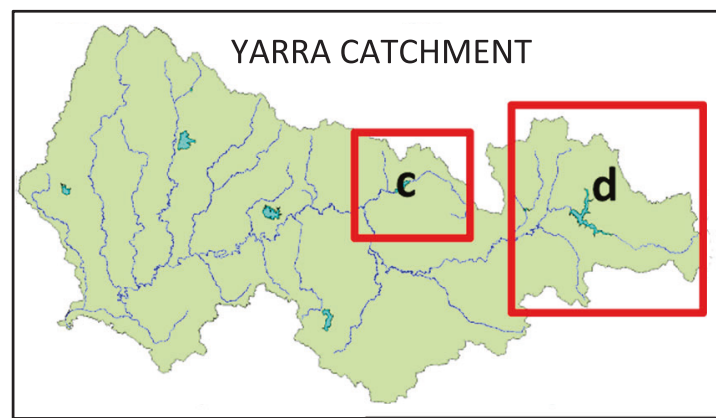

d)

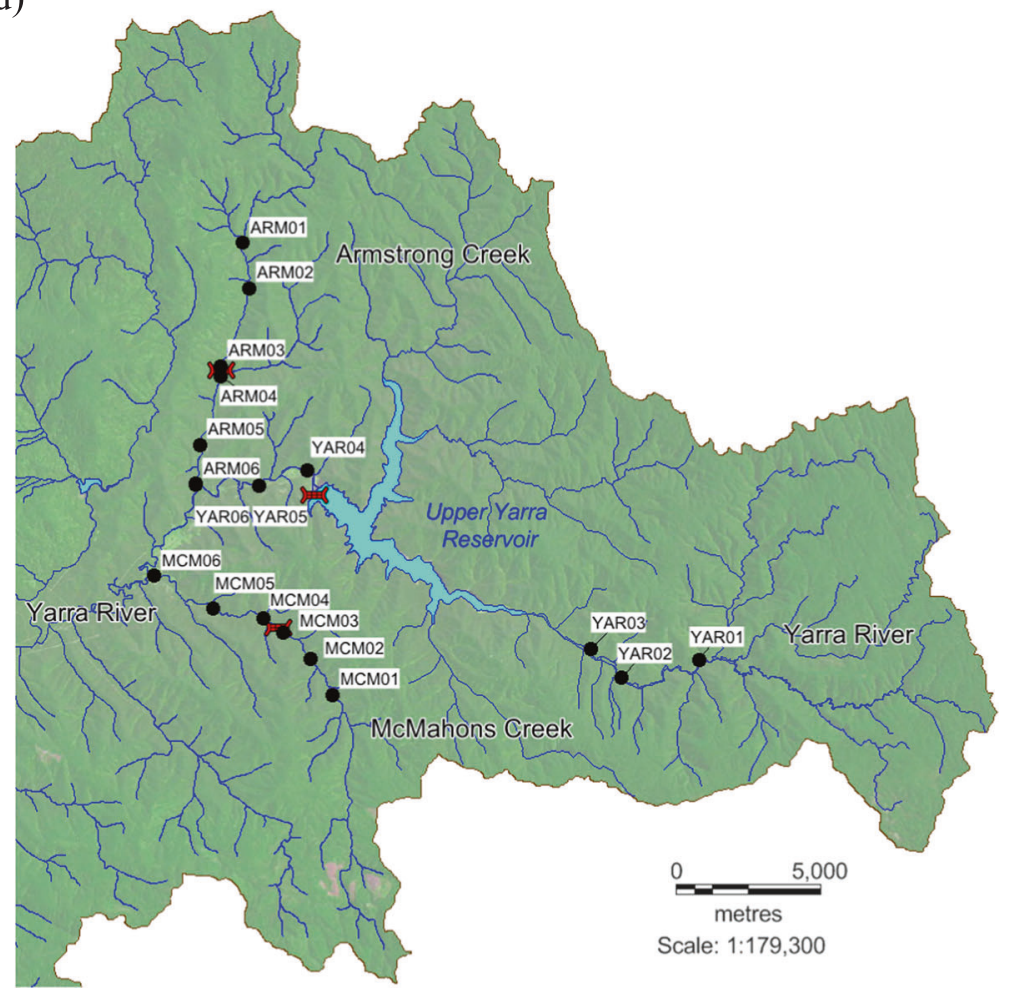

= Study site

Fig. 1 Yarra River catchment, the location of water supply weirs and study sites. ARM Armstrong Creek, DON Donnellys Creek, MCM McMahons Creek, WAT Watts River, YAR Yarra River

with fish size (Jackson, 1978; Sanger, 1986; Jackson et al., 1996). Although movement of all life stages of G. marmoratus is poorly understood, adults have a very small home range, usually $<30 \mathrm{~m}$ of channel length, with occasional longer movements of up to $200 \mathrm{~m}$ (Koehn, 1986; Khan et al., 2004; Koster and Crook, 2008).

\section{Sample collection}

Between 2 April 2012 and 14 March 2013, a total of 366 G. marmoratus were caught using a backpack electrofishing unit (Smith-Root, Vancouver, WA, USA) from 28 sites across five streams (Fig. 1; Supplementary Table S1). A total of 24-45 individuals were sampled from 2 to 3 sites above and 2 to 3 sites below each barrier. At each site, backpack electrofishing (Smith-Root Model 20b) was undertaken to sample between 50 and $600 \mathrm{~m}$ (mean 200, SE 7) of stream in an attempt to collect up to $15 \mathrm{fish}$. Although the goal was to have similar distances between sites above and below each barrier, site selection was constrained by suitable access and the length of each stream. River distances between sample sites, calculated with Network Analyst in Arc GIS 10.4 (ESRI), were 1.4-3.8 km (mean 2.2, SE 0.3) above each barrier and 0.9-5.6 km (mean 2.6, 


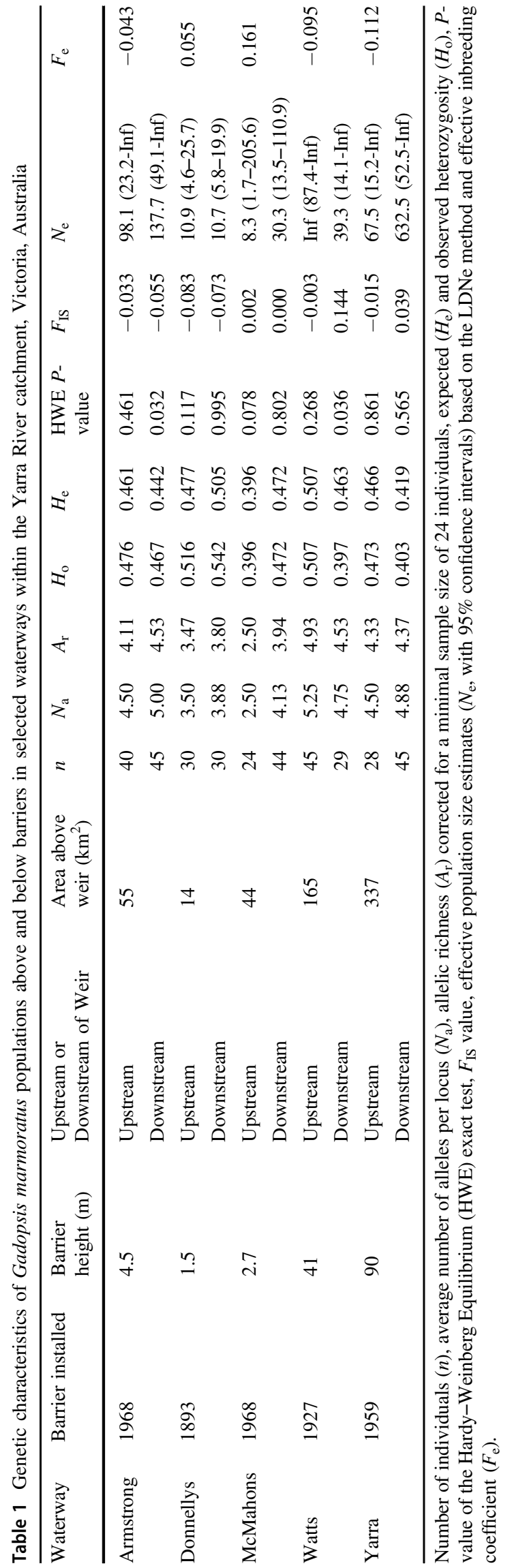

SE 0.5) below each barrier. Total reach length surveyed above each barrier (the distance from the uppermost survey site to the barrier) ranged from 1.4 (Donnellys Creek) to 5.4 $\mathrm{km}$ (Yarra River), with a mean reach length of $3.9 \mathrm{~km}$ (SE 0.8). Total reach length surveyed below each barrier (the distance from the most downstream survey site to the barrier) ranged from 0.9 (Donnellys Creek) to $7.6 \mathrm{~km}$ (Watts River), with a mean reach length of $4.6 \mathrm{~km}$ (SE 1.1). Instream habitat (for example, stream width, riparian vegetation cover, substratum composition) was primarily homogenous across all sites within each stream, and catchment land cover was dominated by forest, except in the Watts River where the catchment below Maroondah Reservoir has been partially cleared for agriculture and the Healesville township. Given the small spatial scale between sample sites in each stream, historical biogeographic factors are unlikely to be influencing population genetic structure above and below each barrier.

The total length and the total weight of each captured individual were measured and a small piece of caudal fin ( $\sim 3-5 \mathrm{~mm}^{2}$ depending on fish size) was collected and preserved in $100 \%$ ethanol prior to being stored in the laboratory at $-20^{\circ} \mathrm{C}$. Fish were released after sampling. In this study, total length of G. marmoratus was $38-455 \mathrm{~mm}$ (mean 216.8, SE 4.7) and weight 1-830 g (mean 136.0, SE 7.2) (see also Supplementary Table S2 in Supplementary Material). To reduce the potential of closely related offspring skewing population assessments, juveniles $<60 \mathrm{~mm}$ total length $(n=5)$ were removed from genetic analyses.

\section{Genetic variation}

Total DNA was extracted from G. marmoratus fin clips using a salting-out DNA extraction protocol (Sunnucks and Hales, 1996) or a DNeasy Blood and Tissue kit (Qiagen, Hilden, Germany). Samples were genotyped using 11 microsatellite DNA markers developed for G. marmoratus (Ling et al., 2013) and amplified in two separate multiplex reactions (Plex A and B) following Beheregaray et al. (2004)—see also Supplementary Appendix S1 in Supplementary Material. Genotypes were determined using GeneMapper v4.0 software (Applied Biosystems, Foster City, CA, USA). Three loci previously found to be variable in other G. marmoratus populations (Gama02, Gama05, and Gama12) were monomorphic in all samples of this study (Supplementary Table S3 in Supplementary Material) and were removed from subsequent analyses, leaving eight polymorphic loci for statistical analyses. Tests for deviations from Hardy-Weinberg for each locus and linkage equilibria for each locus pair were performed using GENEPOP 4.1 (Rousset, 2008) for each sample site, and for 'pooled samples' (the 2-3 sample sites above each barrier in each stream, and the same for below the barrier). This 
pooling was justified because there was no spatial autocorrelation at this spatial scale $(<5.6 \mathrm{~km})$, and even though pooling would tend to increase homozygous excess and linkage disequilibrium, no deviations from Hardy-Weinberg and linkage equilibria were significant after correction for multiple tests (Supplementary Appendices S2 and S3 in Supplementary Material, and Results section). Significance of tests was assessed following a false discovery rate correction for multiple tests (Benjamini and Hochberg, 1995) with a nominal significance level of 5\%. Observed and expected heterozygosities $\left(H_{\mathrm{o}}\right.$ and $\left.H_{\mathrm{e}}\right)$ and Weir and Cockerham's (1984) estimate of $F_{\text {IS }}$ were calculated using GENEPOP 4.1, for each sample site, and for pooled samples (one pool above each barrier in each stream, and one below). Using the rarefaction procedure implemented in FSTAT 2.9.3.2 (Goudet, 1995, 2001; El Mousadik and Petit, 1996), for each locus we calculated allelic richness corrected for sample size $\left(A_{\mathrm{r}}\right)$ for $\geq 6$ individuals at single sample sizes, and $\geq 24$ individuals in the pooled samples.

\section{Regional genetic structure}

To understand the extent to which populations might be interconnected throughout the entire study area, population genetic structure across all sample sites was assessed using Bayesian clustering in STRUCTURE Version 2.2 (Pritchard et al., 2000), with the admixture model and correlated allele frequencies (Falush et al., 2003). To determine the number of clusters $(K)$ within the complete data set, ten replicate runs of $2 \times 10^{6}$ Markov chain Monte Carlo (MCMC) iterations, after an initial burn-in period of $5 \times 10^{5}$ iterations, were performed for values of $K$ ranging from 1 to 10 (the maximum set to the number of pooled samples). Results were summarised using the standard pipeline on the CLUMPAK web server (Kopelman et al., 2015). The most likely number of clusters $(K)$ was explored using the estimated logarithm of likelihood ( $\operatorname{LnP}(\mathrm{D}))$ and the Evanno et al. (2005) $\Delta K$ method that finds the point of greatest change in the distribution of $\operatorname{LnP(D)}$ with STRUCTURE HARVESTER Version 0.6.92 (Earl and vonHoldt, 2012). We further explored genetic structure within the two main infered clusters by analyzing them independently using the same settings (Supplementary Appendix S2 in Supplementary Material).

\section{Assessing the background level of genetic structure}

To assess the extent of background genetic structure, we performed spatial autocorrelation analyses and IBD tests for below-barrier sample sites that are still connected via the mainstem of the Yarra River (that is, nine below-barrier sites in Armstrong Creek, McMahons Creek and Yarra
River, separated by up to $13.2 \mathrm{~km}$ ). Spatial autocorrelation was investigated with SPAGEDI 1.5 (Hardy and Vekemans, 2002), computing the kinship coefficient of Ritland (1996) to assess genetic similarity among pairs of individuals using 2000-m distance class sizes from 0 to $13.2 \mathrm{~km}$ (the maximal distance between two sample sites). The first distance class $(0 \mathrm{~m})$ included individuals caught from the same sampling location. For each distance class, significant deviation of spatial autocorrelation patterns from a random distribution of genotypes was tested by 10,000 random permutations of individuals (for the same sampling location) and individual locations (for the other distance classes). IBD was analysed by regressing pairwise estimates of $F_{\mathrm{ST}} /\left(1-F_{\mathrm{ST}}\right)$ against river distance between sample sites (Rousset, 1997), and tested using a Mantel test (10,000 permutations) with GENEPOP 4.1. Similar analyses were not performed for the Watts River sub-catchment due to low number of samples and low sample sizes below barriers.

\section{Comparing differentiation across barriers to background level of differentiation}

To compare genetic differentiation across barriers to background levels of genetic differentiation, we used the pooled samples above and below each barrier within each stream. Using FSTAT, we calculated Weir and Cockerham (1984) pairwise $F_{\mathrm{ST}}$ values: (1) above versus below each barrier, and (2) between the below-barrier samples in each subcatchment (Watts River or Upper Yarra). The significance of $F_{\mathrm{ST}}$ values was determined using 45,000 permutations. We also explored $D_{\text {est }}$ values, which more accurately account for differences in allelic diversity than does $F_{\mathrm{ST}}$ (Jost, 2008), calculated with GENALEX Version 6.5 (Peakall and Smouse, 2012). However, since $D_{\text {est }}$ values did not show different patterns than $F_{\mathrm{ST}}$, we only report $D_{\text {est }}$ values but do not discuss them further.

\section{Assessing the effect of barriers on genetic diversity and inbreeding}

To test for differences in genetic diversity above and below each barrier, $A_{\mathrm{r}}$ was used instead of $H_{\mathrm{e}}$ because it is more sensitive to recent reductions in population size (Schwartz et al., 2007). Linear mixed models were run using the "Imer" function implemented in the lme4 package (Bates et al., 2015) in R 3.1.3, with $A_{\mathrm{r}}$ at individual sample sites as the response variable. The location of sample sites relative to barriers (weir_side, two levels- above- and below barrier) was included as a fixed factor. Because progressive loss of genetic diversity through drift in small, isolated populations above barriers was expected to depend on: i) population size above the barrier and ii) the number of generations since isolation, we included a fixed factor (catchment_type, two 
levels) separating the two rivers with large catchments (Yarra and Watts rivers) from the three creeks with small catchments (Donnellys, Armstrong and McMahons creeks) as a proxy for population size, and the age of the barrier (weir_age) as a proxy for the number of generations since isolation of above-barrier populations. We also included the pairwise interactions weir_side:catchment_type and weir_side:weir_age. Locus identity was included as a random intercept. Models were validated a posteriori by checking plots of residuals. Significance of fixed effects was assessed with analysis-of-deviance tables (function Anova in the R package car). Post-hoc comparisons of mean allelic richness between populations above and below barriers (pooled into small streams and large rivers separately) was performed using the "lsmeans" function implemented in the lsmeans package (Lenth, 2016) for R 3.1.3.

To approximate inbreeding due to small $N_{\mathrm{e}}$, heterozygosity can be scaled by the heterozygosity of a known outbred population using the effective inbreeding coefficient " $F_{\mathrm{e}}$ " that is, $F_{\mathrm{e}}=1-H_{\mathrm{e} \text { inbred }} / H_{\mathrm{e} \text { outbred, }}$, where $H_{\mathrm{e} \text { inbred }}$ is heterozygosity (for neutral variation) of a population in question and $H_{\mathrm{e}}$ outbred is heterozygosity of an outbred population (Frankham, 1998). We assumed that the pooled samples below each barrier in each stream are not impacted by isolation, and thus can be used as the outbred reference for above-barrier sites in the respective stream. At $F_{\mathrm{e}}$ of $>0.2$, inbreeding depression is typically observed for populations of naturally outcrossing species (Frankham, 1995; Woodworth et al., 2002; Szulkin and Sheldon, 2007; Walling et al., 2011), and major reductions in lifetime reproductive success can occur even below $F_{\mathrm{e}}$ of 0.1 (Huisman et al., 2016).

\section{Testing for bottlenecks and estimating effective population size $\left(\mathrm{N}_{\mathrm{e}}\right)$}

To test for evidence of recent reductions in effective population size that might relate to disturbance events, we used BOTTLENECK (Cornuet and Luikart, 1996) on the pooled samples above or below each barrier within each stream. BOTTLENECK performs a test of heterozygosity excess that compares observed results to theoretical expectations based on a population at equilibrium. Tests were performed using the stepwise mutation model (SMM) and the two-phase model of mutation (TPM), although TPM is likely to be more suitable for most microsatellite loci (Cornuet and Luikart, 1996). Default settings considered appropriate for most microsatellites were applied that is, variance for TPM 30, with $70 \%$ of mutations following SMM. Wilcoxon's signed-rank test was applied to determine significance of a heterozygosity excess based on 1,000 iterations (Cornuet and Luikart, 1996).
Effective population sizes $\left(N_{\mathrm{e}}\right)$ were estimated using the linkage disequilibrium method (LDNe) (Waples and Do, 2008) in NeESTIMATOR V2.0 (Do et al., 2014). $N_{\mathrm{e}}$ was calculated for the pooled samples, as estimates from small sample sizes are not reliable (Tallmon et al., 2010). A threshold of $2 \%$ was applied to remove rare alleles, which have been shown to bias estimates. The LDNe method makes the following important assumptions: (1) loci are selectively neutral and unlinked, (2) populations are closed, and (3) generations are discrete. Due to low dispersal and breeding likely constrained to small local areas, G. marmoratus fail to meet the second assumption. Our estimates do not reflect the global (above or below barrier) 'population' but reflect the effective size in the sampled area (Neel et al., 2013). In addition, because G. marmoratus are iteroparous and have overlapping generations, they also fail to meet the third assumption. Thus, it is possible that $N_{\mathrm{e}}$ estimates from this study are downwardly biased by more than $50 \%$ (Waples et al., 2014). Nevertheless, $N_{\mathrm{e}}$ estimates provide useful comparisons between streams, and between populations above and below each barrier.

\section{Assessing the effect of a barrier, accounting for background genetic structure}

To evaluate our power to detect an effect of a barrier through time for various $N_{\mathrm{e}}$ values and using a space-fortime substitution design (in the absence of temporal data, contemporary spatial patternsare observed to infer likely historical or future changes, see for example, Blois et al. 2013), we ran simulations using a generation-by-generation coalescent algorithm that can simulate spatially limited dispersal (and resulting background genetic structure), implemented in IBDsim 2.0 (Leblois et al. 2003, 2009). Consistent with our G. marmoratus data set for each stream, simulated data sets had 90 diploid individuals genotyped at 8 independent microsatellite loci. Mutations of the microsatellite loci followed a generalised stepwise mutation model with variance of 0.36 and a maximum range of allelic states of 60 . We fixed the mutation rate to 0.0003 , which resulted in ranges of expected heterozygosity values similar to those observed in our data. We simulated a single stream as a linear network with 160 nodes and $200 \mathrm{~m}$ between two successive nodes, and sampled 15 individuals per node, every 10 nodes, for 9 nodes starting from the $70^{\text {th }}$ node (Supplementary Fig. S4). The barrier was placed between nodes 125 and 126. This spatial model reflected a scenario where the stream was connected to a larger downstream system with a much smaller upstream catchment. Sampled nodes were subsequently pooled to mimic the spatial design of our real data set (Supplementary Fig. S4). We ran simulations for three dispersal scenarios: (1) Panmixia, (2) IBD, and (3) IBD + asymmetric migration. For each 
dispersal scenario, we ran simulations for three effective densities $\left(D_{\mathrm{e}}\right): 3,10$ and 30 individuals per node (or 15, 50 and 150 individuals per $\mathrm{km}$ of stream) to cover the range of population sizes in each study stream. According to the formula $N_{\mathrm{e}}=N_{\mathrm{t}} /\left(1-F_{\mathrm{ST}}\right)$ (Wright 1943), where $N_{\mathrm{t}}$ is the total number of individuals, these densities correspond to $N_{\mathrm{e}}$ values for above-barrier populations of $\sim 110,370$ and 1100 individuals, respectively. Limited dispersal for the $I B D$ scenario was simulated using a geometric dispersal distribution. Dispersal was spatially limited to obtain levels of genetic structure that were compatible with the values observed in the Yarra River sub-catchment (based on IBD regression slopes among sample sites and pairwise $F_{\mathrm{ST}}$ values among the pooled samples below each barrier). Maximal dispersal distance was set to 40 nodes, the emigration rate $(e)$ and geometric distribution parameter $(g)$ were set to $0.5 / 0.95,0.25 / 0.9$ and $0.15 / 0.85$ for $D_{\mathrm{e}}$ of 3,10 and 30 individuals per node, respectively. To evaluate the impact of asymmetric migration across the barrier, we ran an IBD + asymmetric migration scenario with the same set of parameters, while allowing downstream gene flow at a rate of 0.2. To compare simulation results with a more typical scenario where there is no genetic structure along each stream prior to the installation of barriers, we also ran a Panmixia scenario, for which the maximum dispersal distance was set to 160 nodes (the size of the network), the emigration rate $(e)$ and the geometric distribution parameter $(g)$ were set to $1 / 1$. For each dispersal scenario and effective density, 50 data sets were simulated assuming no barrier and assuming a complete barrier introduced at various number of generations prior to sampling $(5,10,15,20,25$, 50 and 100), chosen to incorporate the range of barrier ages observed in our study area (45-120 years or 9-24 generations).

For 50 data sets simulated with each combination of parameters (dispersal, $D_{\mathrm{e}}$ and age of the barrier), we calculated allelic richness in pooled sampled nodes above (nodes 130, 141 and 151) and below the barrier (nodes 100, 110 and 120), and IBD regression slopes for the simulations without a barrier using the GENEPOP 4.1 and adegenet package in $\mathrm{R}$ 3.1.3. Weir and Cockerham's pairwise $F_{\mathrm{ST}}$ was calculated using genpop for each locus and globally among (i) pooled sampled nodes 130, 141, and 151 (above the barrier at node 126) and pooled sampled nodes 100, 110 and 120 (below the barrier at node 126), and (ii) among pooled sampled nodes 100,110 and 120 and 70,80 and 90 (all below the barrier at node 126). To determine whether pairwise $F_{\mathrm{ST}}$ values between pooled nodes above and below the barrier were significantly higher than pairwise $F_{\text {ST }}$ values between pooled nodes below the barrier, we used a paired Wilcoxon test and each locus as replicate unit. We also conducted similar Wilcoxon tests using the observed data, where pairwise $F_{\mathrm{ST}}$ values between pooled sites above and below each barrier were compared to pairwise $F_{\mathrm{ST}}$ values between pooled sites below barriers, but connected via the Yarra River mainstem, within each sub-catchment. Finally, to evaluate our power to detect an effect of a barrier with more markers, we ran the same simulations with 20 microsatellite loci and the same characteristics as above.

\section{Results}

\section{Low levels of genetic variation}

Genotypic data revealed low levels of genetic diversity at eight polymorphic microsatellite loci, with the number of alleles per locus ranging from 3 to 14 per population (Supplementary Table S1 and S3 in Supplementary Material). After false discovery rate correction, there was no significant departure from HWE for any sample site, or for the pooled samples above and below each barrier (Table 1, Supplementary Table S1). No pair of loci showed significant LD. Within the pooled samples, observed and expected heterozygosities were between $0.396-0.516$ and $0.396-0.507$, respectively, and allelic richness ranged from 2.50 to 4.93 (Table 1). At individual sample sites, observed and expected heterozygosities were between $0.266-0.583$ and 0.362-0.534, respectively, and allelic richness ranged from 2.12 to 3.52 (Supplementary Table S1).

\section{Regional and local population genetic structure}

The most likely value of $K$ from the STRUCTURE analysis based on the method of Evanno et al. (2005) was two (Supplementary Table S4 in Supplementary Material), differentiating the two geographically distinct sub-catchments, namely, the Watts River sub-catchment and the upper Yarra River sub-catchment (Fig. 2a). However, $\operatorname{LnP}(K)$ was highest for $K=3$ (Supplementary Table S4 in Supplementary Material). With $K=3$, STRUCTURE identified a third cluster corresponding to samples above the barrier in McMahons Creek (Fig. 2b). Lack of further fine-sale structure within the upper Yarra River sub-catchment was confirmed by a separate analysis of this sub-catchment (Supplementary Appendix S2 in Supplementary Material). Separate analysis of the Watts River sub-catchment revealed a cluster represented predominantly in the abovebarrier samples of the Watts River when $K=2$ was assumed (Supplementary Appendix S2 in Supplementary Material).

Spatial genetic autocorrelation analysis between pairs of individuals below barriers in the Yarra River sub-catchment showed significant and positive kinship values for the first distance class only (Fig. 3a), suggesting limited migration rates in the species. Furthermore, genetic similarity between 
a)

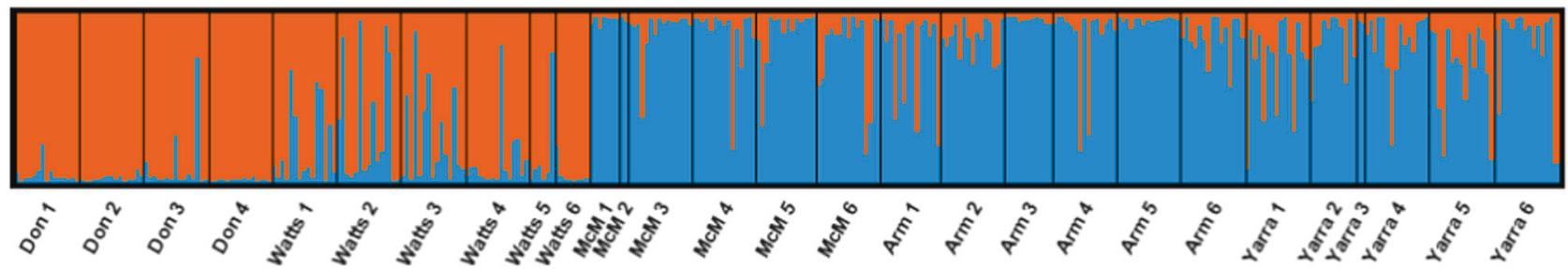

b)

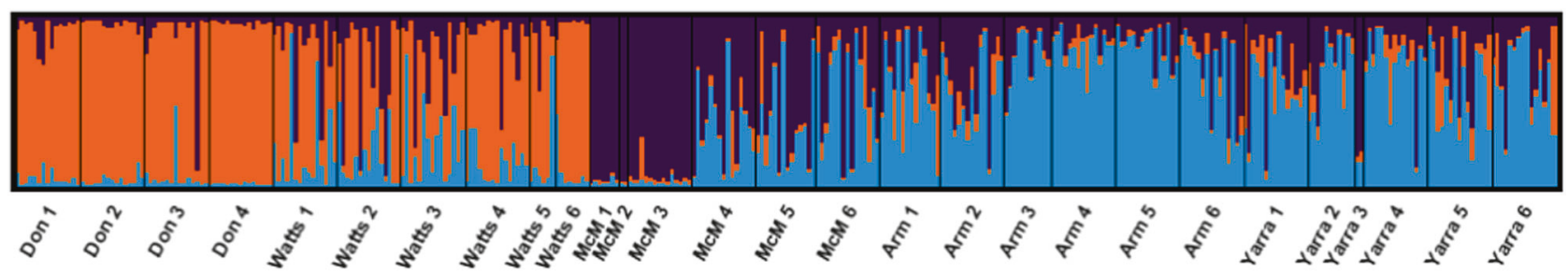

Fig. 2 Summary of results of STRUCTURE analysis for $K=2 \mathbf{a}$ and $K=3 \mathbf{b}$ : plots indicate proportional assignment of individuals (bars) to the colour-coded genetic clusters. The population of origin is indicated on the $x$ axis in upstream to downstream order for each stream
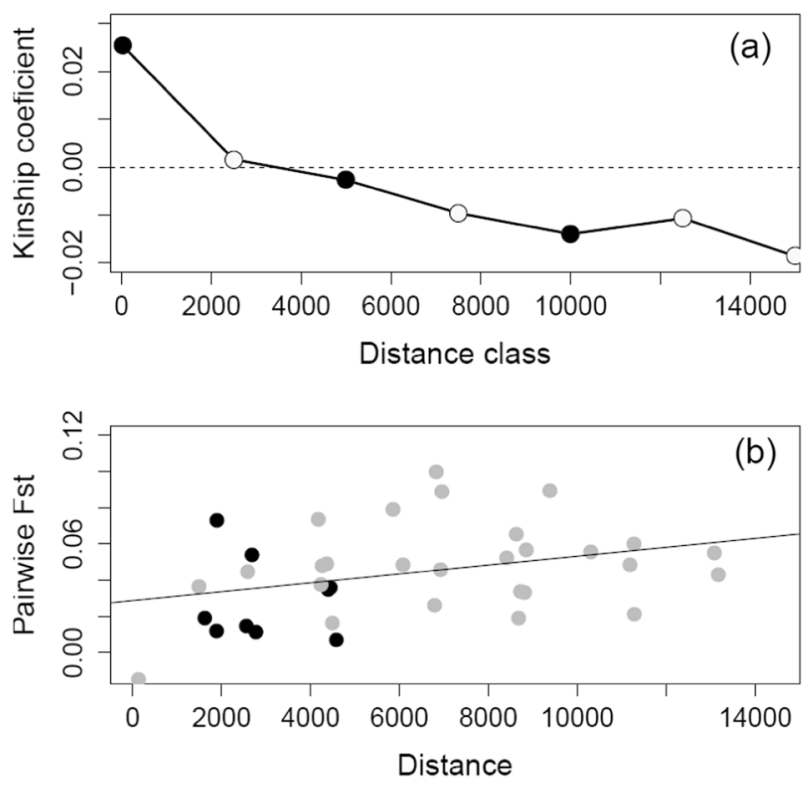

Fig. 3 a Autocorrelogram showing the Ritland kinship coefficient (Ritland, 1996) as a function of distance (expressed in metres) on pairs of individuals from below-barrier sample sites of the Yarra River subcatchment. The first distance class represents pairwise comparisons between individuals from the same sampling location. Filled dots indicate departure from the $95 \% \mathrm{CI}$ for the null hypothesis of a random distribution of genotypes determined by 10,000 random permutations of individuals (first distance class) and individual locations (for the other distance classes). b Pairwise $F_{\mathrm{ST}}$ among sample sites regressed over distance in the Yarra River sub-catchment. Black dots represent pairwise $F_{\mathrm{ST}}$ values between sample sites above and below barriers in each stream, while grey dots represents pairwise $F_{\mathrm{ST}}$ values among all nine sites below barriers individuals decreased from 0 to $10 \mathrm{~km}$, suggesting IBD at this scale. A pattern of IBD was suggested by the positive relationship between genetic differentiation and spatial distance among below-barrier sample sites in the Yarra River sub-catchment, although slightly below statistical significance (Fig. 3b, Slope $=2.61 \times 10^{-6}, 95 \%$ CI: $\left(-8.24 \times 10^{-7}-6.23 \times 10^{-6}\right)$ with distance expressed in metres, Mantel test $P$-value $=0.069$ ).

\section{Comparing differentiation across barriers to background differentiation}

Pairwise $F_{\mathrm{ST}}$ values between all pooled sites were all significantly different from zero (Table 2). Pairwise $F_{\mathrm{ST}}$ values between above- and below-barrier pooled samples calculated for each stream $\left(F_{\mathrm{ST}}=0.029-0.038\right)$ were similar to values between the below-barrier samples pooled within each sub-catchment $\left(F_{\mathrm{ST}}=0.023-0.035\right)$. The exception was McMahons Creek, where $F_{\mathrm{ST}}$ between above and below-barrier pooled samples was 0.129.

\section{Effect of barriers on genetic diversity and inbreeding}

Linear mixed modelling did not identify a significant effect of weir_side on allelic richness across all sample sites $(P$ value $=0.086$ ), although allelic richness in above-barrier sample sites was significantly lower in smaller catchments (Donnellys, Armstrong and McMahons creeks) compared to larger catchments (Watts and Yarra rivers) - that is, there was a significant weir_side:catchment_type interaction; estimate $=-0.62$ SE 0.23, $P$-value $=0.007$ (Table 3). In 
Table $2 F_{\mathrm{ST}}$ (lower diagonal) and $D_{\text {est }}$ (upper diagonal) values for Gadopsis marmoratus populations pooled according to stream and either upstream ('us') or downstream ('Ds') of each water supply weir

\begin{tabular}{|c|c|c|c|c|c|c|c|c|c|c|}
\hline Stream & $\mathrm{ARM}_{\mathrm{US}}$ & $\mathrm{ARM}_{\mathrm{DS}}$ & $\mathrm{DON}_{\mathrm{US}}$ & $\mathrm{DON}_{\mathrm{DS}}$ & $\mathrm{MCM}_{\mathrm{US}}$ & $\mathrm{MCM}_{\mathrm{DS}}$ & $\mathrm{WAT}_{\mathrm{US}}$ & $\mathrm{WAT}_{\mathrm{DS}}$ & $\mathrm{YAR}_{\mathrm{US}}$ & $\mathrm{YAR}_{\mathrm{DS}}$ \\
\hline $\mathrm{ARM}_{\mathrm{US}}$ & & 0.032 & 0.115 & 0.115 & 0.148 & 0.027 & 0.062 & 0.065 & 0.038 & 0.023 \\
\hline $\mathrm{ARM}_{\mathrm{DS}}$ & 0.037 & & 0.126 & 0.153 & 0.165 & 0.031 & 0.065 & 0.082 & 0.029 & 0.018 \\
\hline $\mathrm{DON}_{\mathrm{US}}$ & 0.115 & 0.130 & & 0.029 & 0.151 & 0.087 & 0.056 & 0.073 & 0.083 & 0.088 \\
\hline $\mathrm{DON}_{\mathrm{DS}}$ & 0.111 & 0.147 & 0.029 & & 0.155 & 0.109 & 0.057 & 0.034 & 0.128 & 0.103 \\
\hline $\mathrm{MCM}_{\mathrm{US}}$ & 0.162 & 0.183 & 0.161 & 0.157 & & 0.117 & 0.153 & 0.193 & 0.127 & 0.144 \\
\hline $\mathrm{MCM}_{\mathrm{DS}}$ & 0.030 & 0.035 & 0.088 & 0.103 & 0.129 & & 0.060 & 0.079 & 0.017 & 0.026 \\
\hline $\mathrm{WAT}_{\mathrm{US}}$ & 0.062 & 0.067 & 0.054 & 0.053 & 0.151 & 0.059 & & 0.034 & 0.058 & 0.044 \\
\hline $\mathrm{WAT}_{\mathrm{DS}}$ & 0.071 & 0.091 & 0.076 & 0.035 & 0.203 & 0.083 & 0.035 & & 0.092 & 0.056 \\
\hline $\mathrm{YAR}_{\mathrm{US}}$ & 0.042 & 0.034 & 0.085 & 0.119 & 0.143 & 0.018 & 0.057 & 0.096 & & 0.031 \\
\hline $\mathrm{YAR}_{\mathrm{DS}}$ & 0.028 & 0.023 & 0.099 & 0.109 & 0.172 & 0.031 & 0.049 & 0.067 & 0.038 & \\
\hline
\end{tabular}

All pairwise $F_{\mathrm{ST}}$ and $D_{\text {est }}$ estimates are significant after adjustment for multiple comparisons.

ARM Armstrong Creek, DON Donnellys Creek, MCM McMahons Creek, WAT Watts River, YAR Yarra River

Table 3 Linear mixed model results to test the direct effects and interaction of barriers (weir_side), catchment size (catchment_type) and barrier age (weir_age) on Gadopsis marmoratus populations in the Yarra River system

\begin{tabular}{llll}
\hline Explanatory variable & Chisq & Df & $P$-value \\
\hline Fixed effect & & & \\
Weir_side & 2.935 & 1 & 0.086 \\
Catchment_type & 0.125 & 1 & 0.723 \\
Weir_age & 0.001 & 1 & 0.982 \\
Interactions & & & \\
Weir_side: Catchment_type & 7.259 & 1 & $\mathbf{0 . 0 0 7}$ \\
Weir_side: Weir_age & 0.584 & 1 & 0.444 \\
\hline
\end{tabular}

Significant $P$-value is shown in bold

smaller catchments, below-barrier sample sites had significantly higher allelic richness than above-barrier ones (estimate $=0.314$ SE $0.149, P$-value $=0.037$ ), while in larger catchments, there was no significant difference (estimate $=-0.308 \mathrm{SE} 0.175, P$-value $=0.08)$. There was no effect of barrier_age or interaction with catchment_type on allelic richness. The variance estimate for the random intercept on loci was 1.69 (SD 1.3).

The effective inbreeding coefficient $\left(F_{\mathrm{e}}\right)$ calculated in pooled samples above barriers within each stream was positive in Donnelly's Creek $\left(F_{\mathrm{e}}=0.055\right)$ and McMahons Creek $\left(F_{\mathrm{e}}=0.165\right.$, Table 1$)$, suggesting inbreeding in $G$. marmoratus populations within these streams, particularly McMahons Creek.

\section{Bottleneck tests and estimation of $\mathbf{N}_{e}$}

BOTTLENECK test results provided evidence for a recent bottleneck in the pooled samples above McMahons Creek
Table 4 BOTTLENECK results for Gadopsis marmoratus populations upstream and downstream of water supply barriers in the Yarra River system ${ }^{\mathrm{a}, \mathrm{b}}$

\begin{tabular}{lllll}
\hline Waterway & $\begin{array}{l}\text { Upstream or Downstream of } \\
\text { Weir }\end{array}$ & TPM & SMM & $\begin{array}{l}\text { Mode } \\
\text { shift }\end{array}$ \\
\hline Armstrong & Upstream & 0.770 & 0.980 & No \\
& Downstream & 0.656 & 0.961 & No \\
Donnellys & Upstream & 0.230 & 0.629 & No \\
& Downstream & 0.234 & 0.711 & No \\
McMahons & Upstream & $\mathbf{0 . 0 2 0}$ & $\mathbf{0 . 0 3 9}$ & Yes \\
& Downstream & 0.055 & 0.406 & No \\
\multirow{4}{*}{ Watts } & Upstream & 0.371 & 0.844 & No \\
& Downstream & 0.844 & 0.990 & No \\
Yarra & Upstream & 0.594 & 0.852 & No \\
& Downstream & 0.963 & 0.990 & No \\
\hline
\end{tabular}

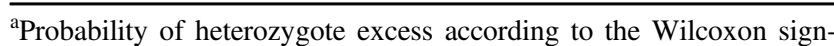
rank test under the TPM (Two-phased model of mutation) and SMM (Stepwise Mutation Model) for each population.

${ }^{\text {b}}$ Significant $P$-values are shown in bold.

weir under the TPM and SMM mutation models, but no bottlenecks were found in any other population (Table 4). Confidence intervals for $N_{\mathrm{e}}$ estimates included infinite values for populations in the Watts and Yarra rivers and in Armstrong Creek, suggesting insufficient power in our data to estimate $N_{\mathrm{e}}$ in these three larger streams (Tallmon et al. 2010). For the pooled samples above and below barriers within the two smallest creeks, small $N_{\mathrm{e}}$ estimates were obtained in Donnellys Creek and were similar above and below the barrier (10.9 and 10.7, respectively), while in McMahons Creek, $N_{\mathrm{e}}$ was lower above than below the barrier (8.3 and 30.8, respectively). 
Table 5 IBDsim simulation parameter summary and mean values based on 50 simulations without a barrier, compared to the observed data set for all sites downstream of barriers in the Yarra sub-catchment

\begin{tabular}{|c|c|c|c|c|c|c|c|}
\hline \multirow[b]{3}{*}{ Density of individuals per $\mathrm{km}\left(D_{\mathrm{e}}\right)$} & \multirow{3}{*}{$\begin{array}{l}\text { Observed } \\
\text { data set }\end{array}$} & \multicolumn{6}{|c|}{ Dispersal scenario } \\
\hline & & \multicolumn{3}{|c|}{ Panmixia } & \multicolumn{3}{|l|}{ IBD } \\
\hline & & 15 & 50 & 150 & 15 & 50 & 150 \\
\hline \multicolumn{8}{|l|}{ Dispersal parameters } \\
\hline maximum dispersal distance & & \multicolumn{3}{|c|}{160 nodes } & \multicolumn{3}{|l|}{40 nodes } \\
\hline emigration rate (e) & & 1 & 1 & 1 & 0.50 & 0.25 & 0.15 \\
\hline geometric distribution $(\mathrm{g})$ & & 1 & 1 & 1 & 0.95 & 0.90 & 0.85 \\
\hline \multicolumn{8}{|l|}{ Summary statistics } \\
\hline IBD slope (SD) & $2.61 \times 10^{-6}$ & NA & NA & NA & $\begin{array}{l}2.395 \times 10^{-6} \\
\left(3.431 \times 10^{-6}\right)\end{array}$ & $\begin{array}{l}3.417 \times 10^{-6} \\
\left(2.562 \times 10^{-6}\right)\end{array}$ & $\begin{array}{l}3.306 \times 10^{-6} \\
\left(1.991 \times 10^{-6}\right)\end{array}$ \\
\hline$F_{\mathrm{ST}}$ above-below node $125(\mathrm{SD})$ & $0.023-0.035$ & $0(0)$ & $0(0)$ & $0(0)$ & $0.027(0.023)$ & $0.029(0.011)$ & $0.027(0.009)$ \\
\hline $\begin{array}{l}\left.A_{r} \text { ratio (pooled nodes } 100,110,120\right) / \\
\text { pooled nodes } 130,140,150)\end{array}$ & & 1.000 & 1.000 & 1.000 & 0.951 & 0.957 & 0.948 \\
\hline$\%$ IBD mantel tests significant & & & & & 28 & 56 & 76 \\
\hline
\end{tabular}

\section{Assessing the effect of a barrier, accounting for background genetic structure}

With limited dispersal (IBD and IBD + asymmetric migration scenarios) and for each effective density, simulated data sets without a barrier yielded pairwise $F_{\mathrm{ST}}$ values among pooled sampled nodes above and below node 126 (barrier location) and IBD regression slopes among sampled nodes consistent with observed values between sample sites below barriers in the Yarra River sub-catchment (Table 5). Simulations with 20 loci indicated increased power to detect sigificant IBD patterns compared to 8 loci, where using the 20 loci, simulation IBD regression slopes ranged from $3.026 \times 10^{-6}\left(\mathrm{SD} 1.992 \times 10^{-6}\right)$ to $3.275 \times 10^{-6}(\mathrm{SD}$ $1.587 \times 10^{-6}$ ) and the percentage of significant Mantel tests ranged from 66 to 96 . This result compares to the simulations with eight loci where regression slopes ranged from $2.395 \times 10^{-6}\left(\mathrm{SD} 3.431 \times 10^{-6}\right)$ to $3.417 \times 10^{-6}(\mathrm{SD}$ $\left.2.562 \times 10^{-6}\right)$ and the percentage of significant Mantel tests ranged from 28 to 76 . Even without a barrier, allelic richness in pooled upstream nodes was slightly lower than in pooled downstream nodes (Supplementary Table S8).

Simulations with a complete barrier suggested that low effective densities $\left(D_{\mathrm{e}}\right)$ would be required for genetic drift to increase $F_{\mathrm{ST}}$ values substantially (for example, $F_{\mathrm{ST}}>0.1$ ) over the number of generations since the installation of barriers in the study area (up to $\sim 25$ generations) regardless of the dispersal scenario (Fig. 4). However, substantial differences in the ability to detect a barrier effect with a space-for-time substitution design were evident between Panmixia and IBD scenarios (Supplementary Table S8). In the Panmixia scenario, within only 15 generations, significantly higher $F_{\mathrm{ST}}$ values were detected across the barrier in more than half the simulated data sets with low and medium effective densities ( 15 and 50 individuals per $\mathrm{km}$ ), while 100 generations are likely to be required in the IBD scenario to reach a similar threshold (Fig. 4). Simulations with asymmetric migration showed that downstream gene flow slightly delays the development of genetic differentiation and the ability to detect a barrier effect (Fig. 4 and Supplementary Table S8). Allelic richness in pooled nodes above the barrier was predicted to progressively decrease with the number of generations since barrier installation.

Variation in $F_{\mathrm{ST}}$ estimates was high among our simulated data sets, and most likely reflects the limited statistical power of eight polymorphic loci. Indeed, simulations with 20 microsatellite loci with same characteristics showed a substantial increase in power to detect barrier impacts (Supplementary Table S9 and Supplementary Fig. S5 in Supplementary Material).

Comparing these simulations with observed pairwise $F_{\mathrm{ST}}$ values above and below each barrier compared to pooled sites below barriers (Supplementary Table S10) and the number of generations since barrier installation for each stream, the above-barrier population of McMahons Creek is likely to have recently experienced strong genetic drift-with effective densities much lower than 15 individuals per $\mathrm{km}$ (global upstream population of $<110$ individuals). This is consistent with our $N_{\mathrm{e}}$ estimate ( 10 individuals over the sampled area) and the detection of a bottleneck. For Donnellys Creek, however, where the barrier is the oldest $(\sim 25$ generations) and $N_{\mathrm{e}}$ was estimated to be similar to McMahons Creek above the barrier, the low level of differentiation $\left(F_{\mathrm{ST}}=0.029\right)$ cannot be attributed to downstream gene flow only. 
Panmixia
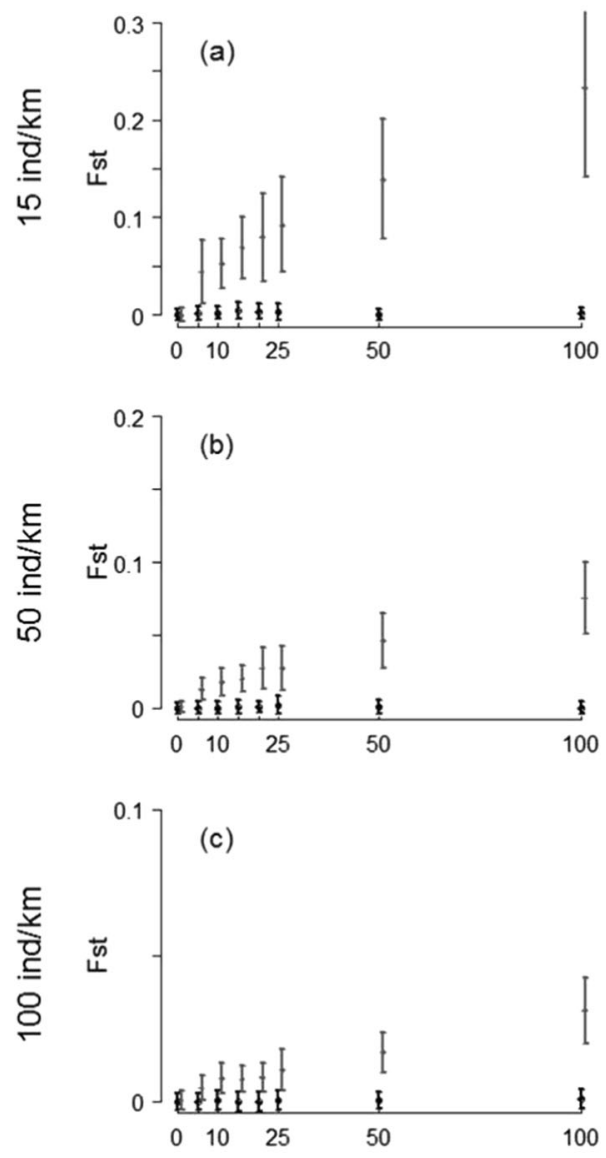

IBD

$\mathrm{IBD}+$ asymmetric gene flow
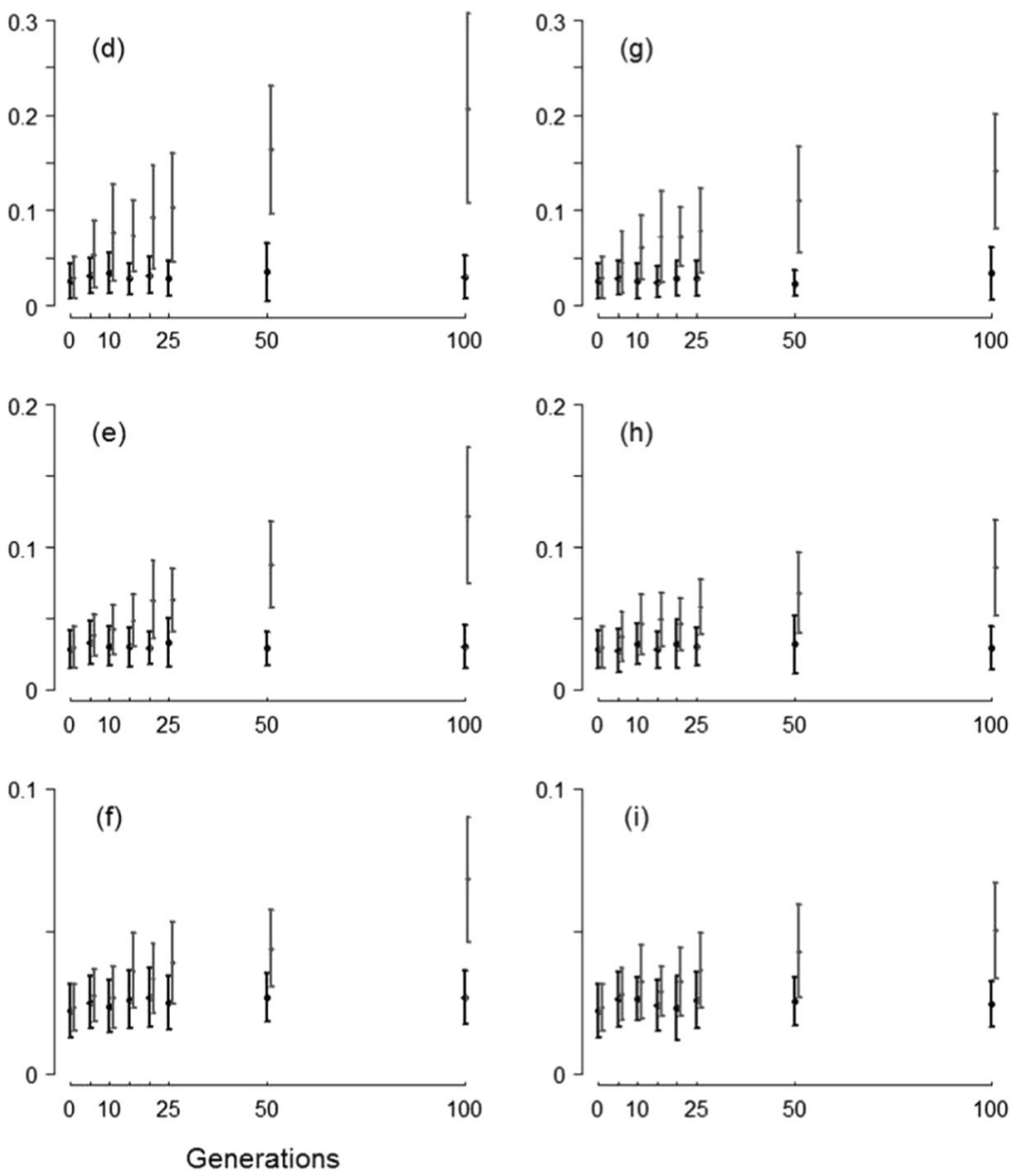

Fig. 4 Simulated increases in population differentiation (pairwise $F_{\mathrm{ST}}$ \pm SD based on 50 simulated data sets) with time (number of generations) using eight microsatellites markers. Pairwise $F_{\mathrm{ST}}$ values are shown (i) between pooled nodes above the barrier (nodes 130, 140 and 150 ) and pooled nodes below the barrier (nodes 100, 110, 120) (grey),

\section{Discussion}

\section{Evaluating the impacts of barriers on low-mobility species}

We sought to address a lack of studies that assess the genetic impacts of artificial barriers on freshwater fish species with low mobility. On the basis of spatially explicit simulations and an extensive empirical data set, our study highlights the importance of accounting for background genetic structure in species of low mobility to avoid falsely attributing genetic impacts to barriers. For example, a simple test of genetic differentiation across a barrier may be insufficient to establish the effect of a barrier alone. In these cases, barrier effects can only be identified if there is a significant increase in genetic differentiation that exceeds background levels of genetic structure. This can be assessed and (ii) among two pools of nodes below the barrier (nodes 100, 110, 120 compared to nodes $100,110,120$ ) (black) per dispersal scenario: Panmixia a-c, IBD d-f and IBD + asymmetric migration $\mathbf{g}-\mathbf{i}$ and effective density: 15 individuals per $\mathrm{km} \mathbf{a}, \mathbf{d}, \mathbf{g}, 50$ individuals per $\mathrm{km}$ $\mathbf{b}, \mathbf{e}, \mathbf{h}$ and 150 individuals per $\mathrm{km} \mathbf{c}, \mathbf{f}, \mathbf{i}$

with temporal sampling (Schwartz et al., 2007) or with a space-for-time substitution study design (such as the present study). Genetic impacts from barriers were most evident in one of our small streams. This result is likely to be associated with a recent bottleneck and restricted gene flow imposed by the barrier that limits population recovery. In the other study streams, a lack of evidence for significant barrier effects can be attributed to larger population sizes or, in the case of the smallest barrier, gene flow across the barrier.

\section{Background levels of genetic structure and diversity}

Genetic differentiation was greatest between the two geographically distinct sub-catchments: the 'Upper Yarra River sub-catchment' (Upper Yarra River, Armstrong Creek and McMahons Creek) and the 'Watts River sub-catchment' 
(Watts River and Donnellys Creek). Given that the two subcatchments are currently hydrologically connected via the mainstem of the Yarra River, differentiation between these two sub-catchments is likely due to the low mobility of $G$. marmoratus (Koehn, 1986; Khan et al., 2004; Koster and Crook, 2008). Within the Yarra River sub-catchment, a pattern of isolation-by-distance was suggested and spatial genetic autocorrelation was significant between individuals at the scale of individual sample sites only. Inference of poor dispersal is consistent with the findings of substantial genetic structure and population differentiation at spatial scales of $<5 \mathrm{~km}$ to 100 's of $\mathrm{km}$ between study sites for northern G. marmoratus within the Murray-Darling Basin (Huey et al., 2017; Lean et al., 2017). While genetic diversity of $G$. marmoratus within the study area was generally low at all sample sites, low genetic diversity was also found within other populations across the broader range of the species complex (Huey et al., 2017; Lean et al., 2017). A strong effect of drift due to restricted migration rates and low population effective size is the most likely explanation and has been suggested to relate either to fragmentation due to human activities or to life history characteristics of the species (Huey et al., 2017; Arias et al., 2013; Lean et al., 2017).

\section{Effects of barriers on population differentiation and genetic diversity in structured populations}

Theory and simulation-based studies predict that the effect of genetic drift on genetic diversity and structure depends on the effective population size and the number of generations since population isolation (Leblois et al., 2006; Gauffre et al., 2008; Landguth et al., 2010). Failing to account for prior population structure at small spatial scales (for example, within streams) for low-mobility species, however, could lead to erroneously attributing natural levels of differentiation to the effect of a barrier; but examples where local background structure is present and explicitly accounted for in tests of barrier effects in freshwater systems appear to be rare. The presence of population structure also results in longer lag times before genetic patterns can be detected (Leblois et al., 2006; Landguth et al., 2010). Our spatially explicit simulations suggest that, even without barriers, we could expect: (i) slightly lower genetic diversity $\left(A_{\mathrm{r}}\right)$ within upper reaches compared to the lower reaches, and (ii) significant differentiation between upper and lower reaches within our study streams. Hence, in non-panmictic populations such as $G$. marmoratus in our study area, significant genetic differentiation $\left(F_{\mathrm{ST}}\right)$ across barriers cannot be solely attributed to barrier effects.

Our simulations also showed that, when a barrier was introduced, if the number of generations since population isolation is low ( $<25$ generations), substantial loss of diversity above a barrier and development of genetic differentiation across barriers will only occur in IBD populations when effective densities are small (for example, 15 individuals per $\mathrm{km}$ ). In addition, when asymmetrical gene flow was taken into account in IBD populations, effects of barriers were unlikely to become evident even in the smallest simulated effective density of 15 individuals per $\mathrm{km}$ for up to 50 generations. Results from the IBD simulations with and without asymmetrical gene flow were in clear contrast to those for panmictic populations. In the simulations for panmictic populations, substantial loss of diversity above a barrier and development of genetic differentiation across barriers can be expected within much smaller timeframes (for example, $<5$ generations for effective densities of up to 50 individuals per $\mathrm{km}$ ) and for larger population densities (for example, $<25$ generations for effective densities up to 150 individuals per $\mathrm{km}$ ). On the basis of our estimates of effective population sizes and number of generations since the presence of barriers ( 9-24), an effect of barriers on genetic structure and diversity was only expected in the two smallest study streams (Donnellys and McMahons creeks).

High variance among simulated data sets reflects the limited ability of a small number of microsatellite markers with low diversity to detect genetic effects (Landguth et al., 2012). This inference was supported results from our simulations using 20 loci, which suggest that impacts from barriers had the potential to be detected much sooner with a greater number of loci (for example, for IBD scenarios with or without asymmetrical gene flow, within 5-10 generations for effective densities of 15 individuals per $\mathrm{km}$ or within 15-50 generations for effective densities of 50 and 100 individuals per $\mathrm{km}$, respectively). Simulations with 20 loci also indicated an increased power to detect IBD compared to eight loci based on the percentage of simulations with a significant Mantel test.

We originally hypothesised that populations isolated upstream of barriers would have lower genetic diversity compared to downstream populations that are more interconnected over a much larger area of habitat. In particular, we hypothesised that genetic diversity in isolated populations upstream of barriers would vary depending on barrier age, the size of the upstream population and disturbance history. Using our observed data set, we found support for the effect of population size, but not the age of the barrier. The size of the populations (based on catchment area) was found to be important for retention of genetic diversity above barriers. Importantly, we cannot relate this result directly to barrier effects, because simulations showed that even in the absence of a barrier upstream, genetic diversity is still expected to be lower above barriers. In addition, contrary to expectations based on simulations, we found more genetic diversity above barriers in the two largest 
streams (upper Yarra and Watts rivers)-indicating likely large densities of individuals above barriers in these two rivers. This finding is consistent with those of Whiteley et al. (2010, 2013), who observed in brook trout (Salvelinus fontinalis) and cutthroat trout (Oncorhynchus clarkii clarkii) populations that the largest patches above barriers had higher genetic diversity than adjacent below-barrier patches, and Gouskov et al. (2016), who observed that large lake populations of European chub (Squalius cephalus) were important for sustaining genetic diversity in fragmented rivers. It is likely that large reservoirs in our system (Maroondah reservoir for the Watts River and upper Yarra reservoir for the Yarra River) sustain large populations and provide refuge habitats for $G$. marmoratus during droughts, such as those experienced in 1982-83 and late 1996-mid 2010.

On the other hand, genetic differentiation across the barrier in McMahons Creek was the highest and was associated with a reduction in genetic diversity above the barrier. This suggests that low diversity is likely to be the driver of the differentiation (similar to the results of Coleman et al. 2013 for dwarf galaxias (Galaxiella pusilla) and Weeks et al. 2016 for Australian mammals). Compared to expectations based on simulations, the population density in McMahons Creek is anticipated to be below the lowest simulated effective density ( $<15$ individuals per $\mathrm{km})$, which is consistent with evidence of a recent bottleneck in the upper McMahons Creek population. One likely explanation for a bottleneck in McMahons Creek is the 1983 wildfires that affected the entire McMahons Creek catchment (Woodgate 1984). Impacts of fire on aquatic ecosystems include a range of chemical, physical and biological changes that can be direct and immediate, as well as indirect and long-term. These impacts are strongest for populations isolated by anthropogenic activities, where fish are unable to recover post-fire via immigration from below into affected areas (Gresswell, 1999; Lyon and O'Connor, 2008). For example, habitat connectivity was inferred to be important for the recovery of rainbow trout (Oncorhynchus mykiss) populations following catchment disturbance from fires, where genetic diversity was lower in populations upstream of barriers due to culverts (Neville et al., 2009). By preventing gene flow following a bottleneck, the water supply weir on McMahons Creek appears to have impeded recovery of the upstream population compared to the downstream population that has greater genetic diversity.

Given that the Donnellys Creek population above the barrier has the smallest catchment and the oldest weir, we expected loss of genetic diversity and elevated pairwise $F_{\mathrm{ST}}$ above and below the barrier. Whilst loss of genetic diversity upstream was lower than expected, $F_{\mathrm{ST}}$ was smaller than predicted in simulations, even with substantial downstream gene flow. This finding suggests that downstream gene flow alone cannot explain results for this stream. Donnellys Creek weir is the lowest of the study barriers ( 1.5 m high), so it is plausible that there has also been some upstream migration of individuals over the weir during extreme stream flows or from undocumented translocations into the upstream weir pool. Homogenisation of gene pools of Roanoke logperch (Percina rex) above and below older (c. $1920)$, but smaller artificial barriers $(\sim 10 \mathrm{~m}$ high $)$, was thought to be associated with at least one-way gene flow across the barrier (Roberts et al., 2013).

\section{Management implications}

In the context of the classic Wright-Fisher model for closed panmictic populations, the minimum effective population sizes necessary for viable isolated populations are estimated to be $\sim 100$ individuals to avoid inbreeding depression in the short-term, and 1000 or more to maintain adaptive potential in the long-term (Frankham et al., 2014). In IBD populations, however, where dispersal is restricted and there is a higher probability that individuals preferentially breed with those in close proximity, detection of genetic impacts such as loss of genetic diversity due to habitat reduction, is expected to differ from panmictic populations for a given population size and temporal scale (Leblois et al., 2006). Accordingly, in order to accurately evaluate the impacts of barriers on species with low mobility and determine the need for management intervention, it is essential to take underlying IBD genetic patterns into account.

Observations of genetic impacts in this study were not related to barrier age and, instead, we demonstrated impacts in one stream within 45 years of isolation (approximately nine generations). The G. marmoratus population above the McMahons Creek weir is likely to be at risk from inbreeding and poor adaptive potential, which is supported by a higher effective inbreeding coefficient $\left(F_{\mathrm{e}}=0.161\right)$. This finding highlights the importance of maintaining population connectivity in small streams where genetic impacts of a barrier due to restricted gene flow following a disturbance event can develop within just a few generations. Immediate actions to improve connectivity and gene flow could include the installation of fishways on the smaller streams showing signs of genetic drift above barriers, as demonstrated for European chub (Gouskov et al., 2016). Where a fishway is not feasible (for example, due to site or cost constraints), intermittent translocations from downstream populations might be advantageous for improving genetic diversity and adaptive potential-especially in upper McMahons Creek, where a recent bottleneck leading to high inbreeding and loss of genetic diversity was detected.

This study indicates that activities aiming to facilitate gene flow for freshwater fish along streams are particularly relevant for small, isolated populations that are more 
vulnerable to disturbance events (such as wildfire or drought) and are currently unable to recover via gene flow from downstream populations. In addition, the need for assisted gene flow is increased for species with low mobility that may take longer to recover from genetic impacts than more mobile species (Landguth et al., 2010). Loss of genetic diversity in these situations must be addressed alongside more commonly considered threats, in this case exemplified by habitat modification (especially removal of large woody debris), sedimentation (for example, smothering of eggs), altered stream flows, interactions with alien species (such as brown trout, Salmo trutta) and recreational fishing (Koehn and O'Connor, 1990; Lintermans, 2007).

To determine the effectiveness of interventions to increase gene flow, genetic monitoring is recommended, that is, collection of tissue samples from populations upstream and downstream of (former) barriers to assess temporal changes in $N_{e}, A_{\mathrm{r}}$, or $H_{\mathrm{e}}$ (see Category II monitoring described in Schwartz et al., 2007). As part of further genetic monitoring and evaluation of the need for genetic intervention in the larger streams, the application of a greater number of markers would be more powerful for early detection of genetic impacts.

\section{Data archiving}

Data available from the Dryad Digital Repository: http://dx. doi.org/10.5061/dryad.hn050.

Acknowledgements This work was supported by an Australian Research Council Linkage Grant (LP110200017) to Monash University, Flinders University of South Australia, the University of Canberra, and University of Montana. Funding and other support was also contributed by industry partner organizations namely, Melbourne Water Corporation, ACTEW Corporation, Victorian Department of Sustainability and Environment (now Department of Environment, Land, Water and Planning) and Fisheries Victoria (now Department of Economic Development, Jobs, Transport and Resources). L.B.B. was supported by an ARC FT130101068 grant. Justin O'Mahony, Renae Ayres, Scott Raymond and Mike Nicol from the Arthur Rylah Institute assisted with the collection of tissue samples. This publication has been written with the support of the AgreenSkills+fellowship programme, which has received funding from the EU's Seventh Framework Programme under grant agreement $\mathrm{N}^{\circ}$ FP7-609398 (AgreenSkills+contract). Part of this work was carried out by using the resources of the INRA MIGALE (http://migale.jouy.inra.fr) and GENOTOUL (Toulouse Midi-Pyrénées) bioinformatics platforms and the Montpellier Bioinformatics Biodiversity platform services. RL was supported by the Agence Nationale de la Recherche (project GENOSPACE ANR-16-CE02-0008). Thanks to Andrew Weeks and anonymous reviewers for useful comments on the early draft of this manuscript.

\section{Compliance with ethical standards}

Conflict of interest The authors declare that they have no conflict of interests.
Open Access This article is licensed under a Creative Commons Attribution 4.0 International License, which permits use, sharing, adaptation, distribution and reproduction in any medium or format, as long as you give appropriate credit to the original author(s) and the source, provide a link to the Creative Commons license, and indicate if changes were made. The images or other third party material in this article are included in the article's Creative Commons license, unless indicated otherwise in a credit line to the material. If material is not included in the article's Creative Commons license and your intended use is not permitted by statutory regulation or exceeds the permitted use, you will need to obtain permission directly from the copyright holder. To view a copy of this license, visit http://creativecommons. org/licenses/by/4.0/.

\section{References}

Allen GR, Midgley SH, Allen M (2002) Field Guide to the Freshwater Fishes of Australia. Western Australian Museum, Perth, Australia.

Angermeier PL (1995) Ecological attributes of extinction-prone species: loss of freshwater fishes of Virginia. Conserv Biol 9:143-158.

Arias M, Atteke C, Augusto S, Bailey J, Bazaga P, Beheregaray LB, Benoit L, Blatrix R, Born C, Brito R (2013) Permanent genetic resources added to Molecular Ecology Resources Database 1 February 2013-31 March 2013. Mol Ecol Res 13:760-762.

Bates D, Maechler M, Bolker B, Walker S (2015) Fitting linear mixedeffects models using lme4. J Stat Softw 67:1-48.

Beheregaray LB, Möller LM, Schwartz TS, Chao NL, Caccone G (2004) Microsatellite markers for the cardinal tetra Paracheirodon axelrodi, a commercially important fish from central Amazonia. Mol Ecol Not 4:330-332.

Beneteau CL, Mandrak NE, Heath DD (2009) The effects of river barriers and range expansion of the population genetic structure and stability in Greenside Darter (Etheostoma blennioides) populations. Conserv Genet 10:477-487.

Benjamini Y, Hochberg Y (1995) Controlling the false discovery rate: a practical and powerful approach to multiple testing. Roy Stat Soc Ser B 57:289-300.

Blois JL, Williams JW, Fitzpatrick MC, Jackson ST, Ferrier S (2013) Space can substitute for time in predicting climate-change effects on biodiversity. Proc Natl Acad Sci USA 110:9374-9379.

Coleman RA, Weeks AR, Hoffmann AA (2013) Balancing genetic uniqueness and genetic variation in determining conservation and translocation strategies: a comprehensive case study of threatened dwarf galaxias, Galaxiella pusilla (Mack) (Pisces: Galaxiidae). Mol Ecol 22:1820-1835.

Cornuet JM, Luikart G (1996) Description and power analysis of two tests for detecting recent population bottlenecks from allele frequency data. Genetics 144:2001-2014.

Costello AB, Down TE, Pollard SM, Pacas CJ, Taylor EB (2003) The influence of history and contemporary stream hydrology on the evolution of genetic diversity within species: an examination of microsatellite DNA variation in bull trout, Salvelinus confluentus (Pisces: Salmonidae). Evolution 57:328-344.

Dehais C, Eudeline R, Berrebi P, Argillier C (2010) Microgeographic genetic isolation in chub (Cyprinidae: Squalius cephalus) population of the Durance River: estimating fragmentation by dams. Ecol Freshw Fish 19:267-278.

Do C, Waples RS, Peel D, Macbeth G, Tillett BJ, Ovenden JR (2014) NeEstimator v2: re-implementation of software for the estimation of contemporary effective population size $\left(N_{e}\right)$ from genetic data. Mol Ecol Res 14:209-214. 
Dudgeon D, Arthington AH, Gessner MO, Kawabata ZI, Knowler DJ, Lévêque $\mathrm{C}$ et al. (2006) Freshwater biodiversity: importance, threats, status and conservation challenges. Biol Rev 81:163-182.

Earl DA, vonHoldt BM (2012) STRUCTURE HARVESTER: a website and program for visualizing STRUCTURE output and implementing the Evanno method. Conserv Genet Resour 4:359-361.

El Mousadik A, Petit RJ (1996) High level of genetic differentiation for allelic richness among populations of the argan tree Argania spinosa (L.) Skeels endemic to Morocco. Theor Appl Genet 92:832-839.

Evanno G, Regnaut S, Goudet J (2005) Detecting the number of clusters of individuals using the software STRUCTURE: a simulation study. Mol Ecol 14:2611-2620.

Falush D, Stephens M, Pritchard JK (2003) Inference of population structure using multilocus genotype data: linked loci and correlated allele frequencies. Genetics 164:1567-1587.

Faulks LK, Gilligan DM, Beheregaray LB (2011) The role of anthropogenic vs. natural in-stream structures in determining connectivity and genetic diversity in an endangered freshwater fish, Macquarie perch (Macquaria australasica). Evol Appl 19:4723-4737.

Feikema PM, Sherwin CB, Lane PNJ (2013) Influence of climate, fire severity and forest mortality on predictions of long term streamflow: Potential effect of the 2009 wildfire on Melbourne's water supply catchments. J Hydrol 488:1-16.

Fischer J, Lindenmayer DB (2007) Landscape modification and habitat fragmentation: a synthesis. Glob Ecol Biogeogr 16:265-280.

Foley JA, DeFries R, Asner GP, Barford C, Bonan G, Carpenter SR et al. (2005) Global consequences of land use. Science 309:570-574.

Frankham R (1995) Conservation Genetics. Ann Rev Genet 29:305-327.

Frankham R (1996) Relationship of genetic variation to population size in wildlife. Conserv Biol 10:1500-1508.

Frankham R (1998) Inbreeding and Extinction - Island Populations. Conserv Biol 12:665-675.

Frankham R (2005) Genetics and extinction. Biol Conserv 126:131-140.

Frankham R, Bradshaw CJA, Brook BW (2014) Genetics in conservation management: Revised recommendations for the 50/500 rules, Red List criteria and population viability analyses. Biol Conserv 170:56-63.

Frankham R (2015) Genetic rescue of small inbred populations: metaanalysis reveals large and consistent benefits of gene flow. Mol Ecol 24:2610-2618.

Gauffre B, Estoup A, Bretagnolle V, Cosson JF (2008) Spatial genetic structure of a small rodent in a heterogeneous landscape. Mol Ecol 17:4619-4629.

Goudet J (1995) FSTAT (Version 1.2): a computer program to calculate $F$-statistics. J Hered 86:485-486.

Goudet J (2001). FSTAT, A Program to Estimate and Test Gene Diversities and Fixation Indices (version 2.9.3). Available from: http://www2.unil.ch/popgen/softwares/fstat.htm.

Gouskov A, Reyes M, Wirthner-Bitterlin L, Vorburger C (2016) Fish population genetic structure shaped by hydroelectric power plants in the upper Rhine catchment. Evol Appl 9:394-408.

Gresswell RE (1999) Fire and aquatic ecosystems in forested biomes of North America. Trans Am Fish Soc 128:193-221.

Hammer M, Wedderburn S, van Weenan J (2009) Action plan for South Australian freshwater fishes. Native Fish Australia (SA) Inc., Adelaide, Australia.

Hammer MP, Unmack PJ, Adams M, Raadik TA, Johnson JB (2014) A multigene molecular assessment of cryptic biodiversity in the iconic freshwater blackfishes (Teleostei: Percichthyidae: Gadopsis) of south-eastern Australia. Biol J Linn Soc 111:521-540.
Hansen MM, Limborg MT, Ferchaud AL, Pujolar JM (2014) The effects of Medieval dams on genetic divergence and demographic history in brown trout populations. BMC Evol Biol 14:1.

Hardy OJ, Vekemans X (2002) SPAGeDi: a versatile computer program to analyse spatial genetic structure at the individual or population levels. Mol Ecol Not 2:618-620.

Huey JA, Balcombe SR, Real KM, Sternberg D, Hughes JM (2017) Genetic structure and effective population size of the most northern population of the Australian river blackfish, Gadopsis marmoratus (Richardson 1848): implications for long-term population viability. Freshw Sci 36:113-123.

Huisman J, Kruuk LE, Ellis PA, Clutton-Brock T, Pemberton JM (2016) Inbreeding depression across the lifespan in a wild mammal population. Proc Natl Acad Sci USA 113:3585-3590.

Jackson PD (1978) Spawning and early development of the river blackfish, Gadopsis marmoratus Richardson (Gadopsiformes: Gadopsidae), in the McKenzie River, Victoria. Aust J Mar Freshw Res 29:293-298.

Jackson PD, Koehn JD, Lintermans M, Sanger AC (1996). Family Gadopsidae. Freshwater blackfishes. In: Freshwater Fishes of South-eastern Australia, 2nd edition (Ed. R.M. McDowall), pp. 186-190. Reed, Sydney, Australia.

Jackson RB, Carpenter SR, Dahm CN, McKnight DM, Naiman RJ, Postel SL et al. (2001) Water in a changing world. Ecol Appl 11:1027-1045.

Jost L (2008) $G_{\mathrm{ST}}$ and its relatives do not measure differentiation. Mol Ecol 17:4015-4026.

Khan MT, Khan TA, Wilson ME (2004) Habitat use and movement of river blackfish (Gadopsis marmoratus R.) in a highly modified Victorian stream, Australia. Ecol Freshw Fish 13:285-293.

Koehn J (1986) Approaches to determining flow and habitat requirements for freshwater native fish in Victoria. In: Campbell IC Ed. Stream Protection: The Management of Rivers for Instream Uses. Chisholm Institute of Technology, Caulfield, Australia, p 95-113.

Koehn JD, O'Connor WG (1990) Threats to Victorian native fish. Vic Nat 107:5-12.

Koehn JD, O'Connor NA, Jackson PD (1994) Seasonal and sizerelated variation in microhabitat use by a southern Victorian stream fish assemblage. Aust J Mar Freshw Res 45:1353-1366.

Kopelman NM, Mayzel J, Jakobsson M, Rosenberg NA, Mayrose I (2015) Clumpak: a program for identifying clustering modes and packaging population structure inferences across $K$. Mol Ecol Res 15:1179-1191.

Koster WM, Crook DA (2008) Diurnal and nocturnal movements of river blackfish (Gadopsis marmoratus) in a south-eastern Australian upland stream. Ecol Freshw Fish 17:146-154.

Landguth EL, Cushman SA, Schwartz MK, McKelvey KS, Murphy M, Luikart G (2010) Quantifying the lag time to detect barriers in landscape genetics. Mol Ecol 19:4179-4191.

Landguth EL, Fedy BC, Oyler-McCance SJ, Garey AL, Emel SL, Mumma M, Wagner HH, Fortin MJE, Cushman SA (2012) Effects of sample size, number of markers, and allelic richness on the detection of spatial genetic pattern. Mol Ecol Res 12:276-284.

Lean J, Hammer MP, Unmack PJ, Adams M, Beheregaray LB (2017) Landscape genetics informs mesohabitat preference and conservation priorities for a surrogate indicator species in a highly fragmented river system. Heredity 118:374-384.

Leblois R, Estoup A, Rousset F (2003) Influence of mutational and sampling factors on the estimation of demographic parameters in a "continuous" population under isolation by distance. Mol Biol Evol 20:491-502.

Leblois R, Estoup A, Streiff R (2006) Genetics of recent habitat contraction and reduction in population size: does isolation by distance matter? Mol Ecol 15:3601-3615. 
Leblois R, Estoup A, Rousset F (2009) IBDSim: a computer package for coalescent simulations under isolation by distance with temporal and spatial heterogeneities. Mol Ecol Res 9:107-109.

Lenth RV (2016) Least squares means: the R package lsmeans. J Stat Softw 69:1-33.

Ling HJ, Sandoval-Castillo J, Hammer MP, Beheregaray LB (2013) Development of microsatellite markers through 454 pyrosequencing for the river blackfish (Gadopsis marmoratus). Mol Ecol Res 13:760-762.

Lintermans M (2007) Fishes of the Murray-Darling Basin: An Introductory Guide. Murray-Darling Basin Authority, Canberra, Australia, MDBC publication 10/07.

Lucas MC, Baras E, Thom TJ, Duncan A, Slavík O (eds) (2001) Migration of Freshwater Fishes. Blackwell Science Ltd., Oxford, $\mathrm{UK}$.

Lyon JP, O'Connor JP (2008) Smoke on the water: Can riverine fish populations recover following a catastrophic fire-related sediment slug? Austral Ecol 33:794-806.

Miller AD, Waggy G, Ryan SG, Austin CM (2004) Mitochondrial 12S rRNA sequences support the existence of a third species of freshwater blackfish (Percicthyidae: Gadopsis) from southeastern Australia. Mem Mus Vic 61:121-127.

Morita K, Yamamoto S (2002) Effects of habitat fragmentation by damming on the persistence of stream-dwelling charr populations. Conserv Biol 16:1318-1323.

Morris SA, Pollard DA, Gehrke PC, Pogonoski JJ (2001) Threatened and potentially threatened freshwater fishes of coastal New South Wales and the Murray-Darling Basin. NSW Fisheries, Sydney, Australia.

Neel MC, McKelvey K, Ryman N, Lloyd MW, Bull RS, Allendorf FW et al. (2013) Estimation of effective population size in continuously distributed populations: there goes the neighborhood. Heredity 111:189-199.

Neville H, Dunham J, Rosenberger A, Umek J, Nelson B (2009) Influences of wildfire, habitat size, and connectivity on trout in headwater streams revealed by patterns of genetic diversity. Trans Am Fish Soc 138:1314-1327.

Nilsson C, Reidy CA, Dynesius M, Revenga C (2005) Fragmentation and flow regulation of the world's large river systems. Science 308:405-408.

Ovenden JR, White RWG, Sanger AC (1988) Evolutionary relationships of Gadopsis spp. inferred from restriction enzyme analysis of their mitochondrial DNA. J Fish Biol 32:137-148.

Peakall R, Smouse PE (2012) GenAlEx 6.5: genetic analysis in Excel. Population genetic software for teaching and research - an update. Bioinformatics 28:2537-2539.

Pritchard JK, Stephens M, Donnelly P (2000) Inference of population structure using multilocus genotype data. Genetics 155:945-959.

Reid GM, Contreras MacBeath T, Csatádi K (2013) Global challenges in freshwater-fish conservation related to public aquariums and the aquarium industry. Int Zoo Yearb 47:6-45.

Ritland K (1996) Estimators for pairwise relatedness and individual inbreeding coefficients. Genet Res 67:175-185.

Rivera-Ortíz FA, Aguilar R, Arizmendi MDC, Quesada M, Oyama K (2014) Habitat fragmentation and genetic variability of tetrapod populations. Anim Conserv 18:249-258.

Roberts JH, Angermeier PL, Hallerman EM (2013) Distance, dams and drift: what structures populations of an endangered, benthic stream fish? Freshw Biol 58:2050-2064.

Rousset F (1997) Genetic differentiation and estimation of gene flow from $F$-statistics under isolation by distance. Genetics 145:1219-1228.

Rousset F (2008) GENEPOP'007: a complete re-implementation of the GENEPOP software for Windows and Linux. Mol Ecol Res 8:103-106.
Ryan SG, Miller AD, Austin CM (2004) Allozyme variation and taxonomy of the river blackfish, Gadopsis marmoratus Richardson, in western Victoria. Proc R Soc Vic 16:191-199.

Sala OE, Chapin FS, Armesto JJ, Berlow E, Bloomfield J, Dirzo R et al. (2000) Global biodiversity scenarios for the year 2100 . Science 287:1770-1774.

Sanger AC (1986) The evolution and ecology of the Gadopsis marmoratus complex. The University of Melbourne, Parkville, Australia, $\mathrm{PhD}$ thesis.

Schwartz M, Luikart G, Waples R (2007) Genetic monitoring as a promising tool for conservation and management. Trends Ecol Evol 22:25-33.

Strayer DL, Dudgeon D (2010) Freshwater biodiversity conservation: recent progress and future challenges. J North Am Benthol Soc 29:344-358.

Sunnucks P, Hales DF (1996) Numerous transposed sequences of mitochondrial cytochrome oxidase I-II in aphids of the genus Sitobion (Hemiptera: Aphidiae). Mol Biol Evol 13:510-524.

Szulkin M, Sheldon BC (2007) The environmental dependence of inbreeding depression in a wild bird population. PLoS One 2(10): e1027.

Tallmon DA, Gregovich D, Waples RS, Scott Baker C, Jackson J, Taylor BL et al. (2010) When are genetic methods useful for estimating contemporary abundance and detecting population trends? Mol Ecol Res 10:684-692.

Taylor EB, Stamford MD, Baxter JS (2003) Population subdivision in westslope cutthroat trout (Oncorhynchus clarki lewisi) at the northern periphery of its range: evolutionary inferences and conservation implications. Mol Ecol 12:2609-2622.

Unmack P, Sandoval-Castillo J, Hammer M, Adams M, Raadik T, Beheregaray LB (2017) Genome-wide SNPs resolve a key conflict between sequence and allozyme data to confirm another threatened candidate species of river blackfishes (Teleostei: Percichthyidae: Gadopsis). Mol Phylogenet Evol 109:415-420.

Walling CA, Nussey DH, Morris A, Clutton-Brock TH, Kruuk LEB, Pemberton JM (2011) Inbreeding depression in red deer calves. BMC Evol Biol 11:318.

Waples RS, Do C (2008) LDNE: a program for estimating effective population size from data on linkage disequilibrium. Mol Ecol Res 8:753-756.

Waples RC, Antao T, Luikart G (2014) Effects of overlapping generations on linkage disequilibrium estimates of effective population size. Genetics 197:769-780.

Weeks AR, Stoklosa J, Hoffmann AA (2016) Conservation of genetic uniqueness of populations may increase extinction likelihood of endangered species: the case of Australian mammals. Front Zool 13:31.

Weir BS, Cockerham CC (1984) Estimating $F$-statistics for the analysis of population structure. Evolution 38:1358-1370.

Whiteley AR, Hastings K, Wenburg JK, Frissell CA, Martin JC, Allendorf FW (2010) Genetic variation and effective population size in isolated populations of coastal cutthroat trout. Conserv Genet 11:1929-1943.

Whiteley AR, Coombs JA, Hudy M, Robinson Z, Colton AR, Nislow $\mathrm{KH}$ et al. (2013) Fragmentation and patch size shape genetic structure of brook trout populations. Can J Fish Aquat Sci 70:678-688.

Whiteley AR, Fitzpatrick SW, Funk WC, Tallmon DA (2015) Genetic rescue to the rescue. Trends Ecol Evol 30:42-49.

Willi Y, Van Buskirk J, Hoffmann AA (2006) Limits to the adaptive potential of small populations. Annu Rev Ecol Evol Syst 37:433-58.

Wofford JE, Gresswell RE, Banks MA (2005) Influence of barriers to movement on within-watershed genetic variation of coastal cutthroat trout. Ecol Appl 15:628-637. 
Woodgate PW (1984) Classification, mapping and assessment of the fire damage in mountain ash forests: Warburton fire 1983. Forests Commission Victoria, Melbourne, Australia, Forest Inventory Report No 47.
Woodworth LM, Montgomery ME, Briscoe DA, Frankham R (2002)

Rapid genetic deterioration in captive populations: causes and conservation implications. Conserv Genet 3:277-288.

Wright S (1943) Isolation by distance. Genetics 28:114-138. 